\title{
Clinical and epidemiological characteristics of children with SARS-CoV-2 infection: a case series in Sinaloa
}

\author{
Giordano Pérez-Gaxiola ${ }^{1 *}$, Rosalino Flores-Rocha ${ }^{1}$, Julio C. Valadez-Vidarte ${ }^{1}$, \\ Melissa Hernández-Alcaraz¹, Gilberto Herrera-Mendoza', and Miguel Á. Del Real-Lugo² \\ ${ }^{1}$ Hospital Pediátrico de Sinaloa Dr. Rigoberto Aguilar Pico; ${ }^{2}$ Unidad de Inteligencia Epidemiológica, Servicios de Salud de Sinaloa. Culiacán, \\ Sinaloa, Mexico
}

\begin{abstract}
Background: The SARS-CoV-2 virus may affect both adults and children. Although COVID-19 has a lower prevalence in infancy and has been described as mild, the clinical characteristics may vary, and there is a possibility of complications. The objectives of this study were to describe the clinical and epidemiological aspects of confirmed COVID-19 pediatric cases in the state of Sinaloa, Mexico, during the first 3 months of the pandemic, and children admitted with COVID-19 to a secondary hospital. Methods: This case series includes all patients with SARS-CoV-2 infection confirmed by PCR (polymerase chain reaction) test, identified in the state epidemiological surveillance system (SISVER) between March 1 and May 31, 2020. Confirmed patients admitted to the Sinaloa Pediatric Hospital (HPS) in the same period are also described. Results: Fifty-one children with SARS-CoV-2 were included, of which ten were admitted to the HPS. The median age was 10 years. The more frequent symptoms were fever (78\%), cough (67\%), and headache (57\%). Most cases were mild or asymptomatic. Three patients with comorbidities died. Only four of ten patients identified in HPS were admitted with the diagnosis of possible COVID-19. Conclusions: SARS-CoV-2 infection in children was mostly mild or asymptomatic, and the clinical presentation varied. There is a possibility of complications, especially in children with comorbidities.
\end{abstract}

Key words: COVID-19. Severe acute respiratory syndrome coronavirus 2. Epidemiology. Signs and symptoms.

\section{Características clínicas y epidemiológicas de la infección por SARS-CoV-2 en niños: serie de casos en Sinaloa}

\section{Resumen}

Introducción: EI SARS-CoV-2 puede afectar tanto a adultos como a niños. Aunque la COVID-19 presenta menor prevalencia en la infancia y se ha descrito como leve, las características clínicas pueden ser variables y existe la posibilidad de complicaciones. Los objetivos de este estudio fueron describir las características clínicas y epidemiológicas de los casos pediátricos confirmados en el Estado de Sinaloa, México, durante los primeros 3 meses de la pandemia, y de los niños con COVID-19 internados en un hospital de segundo nivel. Métodos: Esta serie de casos incluyó pacientes con infección por SARS-CoV-2 confirmados por prueba de reacción en cadena de la polimerasa (PCR), identificados en el Sistema de Vigilancia Epidemiológica de Enfermedades Respiratorias (SISVER) del 1 de marzo al 31 de mayo de 2020. Se describen

Correspondence:

*Giordano Pérez-Gaxiola

E-mail: giordano@ pediatrica.org (http://creativecommons.org/licenses/by-nc-nd/4.0/).
Date of reception: 30-06-2020

Date of acceptance: 17-08-2020

DOI: 10.24875/BMHIM.200002021
Available online: 24-02-2021

Bol Med Hosp Infant Mex. 2021;78(1):18-23

www.bmhim.com 
también las características de todos los niños confirmados en el Hospital Pediátrico de Sinaloa (HPS) en las mismas fechas. Resultados: Se incluyeron 51 niños con infección por SARS-CoV-2, de los cuales 10 fueron internados en el HPS. La mediana de edad fue de 10 años. Los síntomas más frecuentes fueron fiebre (78\%), tos (67\%) y cefalea (57\%). La mayoría de los casos fueron leves o asintomáticos. Tres pacientes con comorbilidad fallecieron. Solo cuatro de diez pacientes identificados en el HPS ingresaron bajo sospecha de COVID-19. Conclusiones: La infección por SARS-CoV-2 en los niños fue, en su mayoría, asintomática o leve, y la presentación fue variable. Existe la posibilidad de que se produzcan complicaciones, principalmente en niños con comorbilidad.

Palabras clave: COVID-19. Coronavirus tipo 2 del síndrome respiratorio agudo grave. Epidemiología. Signos y síntomas.

\section{Introduction}

The coronavirus disease 2019 (COVID-19) pandemic caused by SARS-CoV-2 (severe acute respiratory syndrome type coronavirus 2) began in Wuhan, China, in late 2019. This disease has affected more than 6 million people and has left health and economic implications worldwide ${ }^{1-3}$. The initial characterization was described in adults ${ }^{4}$, but neonatal and pediatric cases began to be identified as the epidemic progressed ${ }^{5-8}$.

Although the prevalence of COVID-19 in children represents a low percentage of all cases reported in different series or cross-sectional studies, ranging from $0.8 \%$ to $2.7 \%^{9-11}$, the number of affected children and their different clinical presentation compared to adults ${ }^{4,12}$ can be a challenge for pediatricians.

In children, SARS-CoV-2 affects males slightly more, as observed in adults. Fever and cough are also the most common symptoms, but with a lower prevalence than in adulthood. Findings in laboratory tests and imaging studies seem to be more variable. Disease severity is lower than in adults $9,10,13-15$, and mortality due to COVID-19 in children is lower than influenza and other respiratory infections ${ }^{16}$.

Despite this, the possibility of complications, intensive care requisition, and mechanical ventilation exists ${ }^{11,17,18}$. In addition, a possible association between COVID-19 and a condition similar to severe Kawasaki disease called multisystem inflammatory syndrome is being studied ${ }^{19-22}$.

The objectives of this study were to describe the clinical and epidemiological characteristics of the confirmed COVID-19 pediatric cases in the state of Sinaloa, Mexico, and to describe the characteristics of the patients admitted to the Hospital Pediátrico de Sinaloa Dr. Rigoberto Aguilar Pico.

\section{Methods}

During the first 3 months of the pandemic in Sinaloa (March, April, and May 2020), clinical and epidemiological information of pediatric patients with SARS-CoV-2 infection was collected. The disease was confirmed by polymerase chain reaction (PCR) test of respiratory secretions. The patients were identified in the Sistema de Vigilancia Epidemiológica de Enfermedades Respiratorias (Epidemiological Surveillance System of Respiratory Diseases, SISVER) of the Secretaría de Salud (Ministry of Health). At the time of sampling for PCR, demographic data were obtained. These data included if patients had contact with SARS-CoV-2-positive individuals (defined as any person, household, or outside with a positive PCR confirmation test who had been in close contact with the child for more than $15 \mathrm{~min}$, without wearing personal protection equipment, in the previous week), signs, and symptoms. The characteristics were extracted and recorded in a pre-established format. Patients were followed up by telephone at least 2 weeks after the date of onset of symptoms. We attempted to contact everyone twice by phone, sent a WhatsApp message, and asked for their verbal consent to participate in this study. The same format was used to record information on positive patients admitted to the Hospital Pediátrico de Sinaloa. This second-level public hospital serves as a referral center for Sinaloa and surrounding states. We also describe laboratory tests and imaging studies ordered by the treating physician.

Patients were classified according to the severity of illness based on clinical syndromes defined by the World Health Organization ${ }^{23}$ : asymptomatic, mild (upper respiratory infection), moderate (pneumonia), severe (severe pneumonia), or critical (severe acute respiratory syndrome SARS, sepsis, or septic shock) disease. Epidemiological and clinical characteristics are presented in a descriptive manner using absolute numbers and percentages, or medians and interquartile ranges. The analysis was performed using Excel version 16.37.

\section{Results}

Between March 1 and May 31, 2020, 3434 SARS-CoV-2 positive cases were confirmed in the state 
Table 1. Characteristics of children with severe acute respiratory syndrome coronavirus 2 infection in Sinaloa

\begin{tabular}{|c|c|}
\hline Characteristics & $N=51$ \\
\hline $\begin{array}{l}\text { Age in years } \\
\text { Median (IQR) }\end{array}$ & $10(11)$ \\
\hline Distribution & n (\%) \\
\hline $\begin{array}{l}0 \text { a } 28 \text { days } \\
29 \text { days to }<1 \text { year } \\
1 \text { year to }<3 \text { years } \\
3 \text { years to }<6 \text { years } \\
6 \text { years to }<12 \text { years } \\
12 \text { years to } 18 \text { years }\end{array}$ & $\begin{array}{c}2(4) \\
6(12) \\
4(8) \\
4(8) \\
15(29) \\
20(39)\end{array}$ \\
\hline $\begin{array}{l}\text { Sex } \\
\text { Male } \\
\text { Female }\end{array}$ & $\begin{array}{l}26(51) \\
25(49)\end{array}$ \\
\hline & $\mathrm{n} / \mathrm{N}(\%)$ \\
\hline Positive contact & $33 / 47(70)$ \\
\hline $\begin{array}{l}\text { Symptoms } \\
\text { Fever } \\
\text { Cough } \\
\text { Headache or irritability } \\
\text { Odynophagia } \\
\text { Rhinorrhea } \\
\text { Vomit } \\
\text { Diarrhea }\end{array}$ & $\begin{array}{l}40 / 51(78) \\
34 / 51(67) \\
28 / 49(57) \\
10 / 49(20) \\
10 / 50(20) \\
5 / 49(10) \\
7 / 51(14)\end{array}$ \\
\hline
\end{tabular}

IQR: interquartile range.

of Sinaloa: 51 (1.5\%) of them were under 18 years old. Of the 51 children and adolescents, 26 were male (51\%), and the median age was 10 years (interquartile range 11). A positive contact was identified in 33 children.

The most frequent symptoms were fever $(78 \%)$, cough $(67 \%)$, headache or irritability $(57 \%)$, odynophagia $(20 \%)$, and rhinorrhea (20\%). Vomiting and diarrhea were reported in 10 and 14\%, respectively (Table 1). Three children were identified with cancer, one with chronic kidney disease and hypertension, three with obesity, one with a lung abscess and sequelae from a head injury.

We contacted 37 patients to verify their clinical evolution and classify them according to the severity of the disease. Seven children were asymptomatic (19\%), 23 with mild $(62 \%)$, three with moderate $(8 \%)$, one with severe $(3 \%)$, and three with critical $(8 \%)$ disease (Table 2). Asymptomatic children were identified by contact tracing when any of their relatives were positive. Three deaths were reported in three children with comorbidities: a 4-month-old male with Down syndrome, congenital heart disease, and hypothyroidism; an 11-year-old male with chronic kidney disease and hypertension; and a 14-year-old male with sequelae from head injury who suffered a concomitant lung abscess. These patients showed a progression of
Table 2. Severity of the disease in children with SARSCoV-2 (severe acute respiratory syndrome coronavirus 2) infection in Sinaloa

\begin{tabular}{|l|c|}
\hline Category & $\begin{array}{c}\text { Number of children } \\
(\mathbf{n}=\mathbf{3 7})\end{array}$ \\
\hline Asymptomatic & 7 \\
\hline Mild & 23 \\
\hline Moderate & 3 \\
\hline Severe & 1 \\
\hline Critical & 3 \\
\hline
\end{tabular}

respiratory disease. No thrombotic phenomena or severe vasculitis were identified.

The characteristics of ten children admitted to the Hospital Pediátrico de Sinaloa are described in Table 3. The reasons for admission were diverse. In four patients, COVID-19 was suspected since admission (patients 5, 6, 8, and 10). The other six patients were admitted for different reasons. However, as they later developed fever and cough, SARS-CoV-2 infection was suspected. Two had been hospitalized for accidents. A patient with acute lymphoblastic leukemia (ALL) had undergone chemotherapy. Another patient was admitted for pancytopenia and de novo ALL diagnosis. One more patient was admitted because of ventriculoperitoneal valve dysfunction. Another patient diagnosed with Down syndrome, ventricular septal defect (VSD), and hypothyroidism had been hospitalized for more than 2 months. This last patient developed a critical illness and died. The other nine patients presented mild (seven) or moderate (two) disease and were discharged due to improvement. In four patients, the infection was considered to be hospital-acquired. Seven patients had normal leukocytic and lymphocytic count. Leukemia patients (three) showed leukopenia, and one patient with pertussis-like illness showed leukocytosis. A ground-glass pattern in lung tomography was demonstrated in six children; five patients had only mild disease symptoms with the upper respiratory infection symptoms.

\section{Discussion}

This case series illustrates the clinical and epidemiological characteristics of children infected with SARS-CoV-2 during the first 3 months of the pandemic in Sinaloa. The ratio of pediatric cases relative to total 


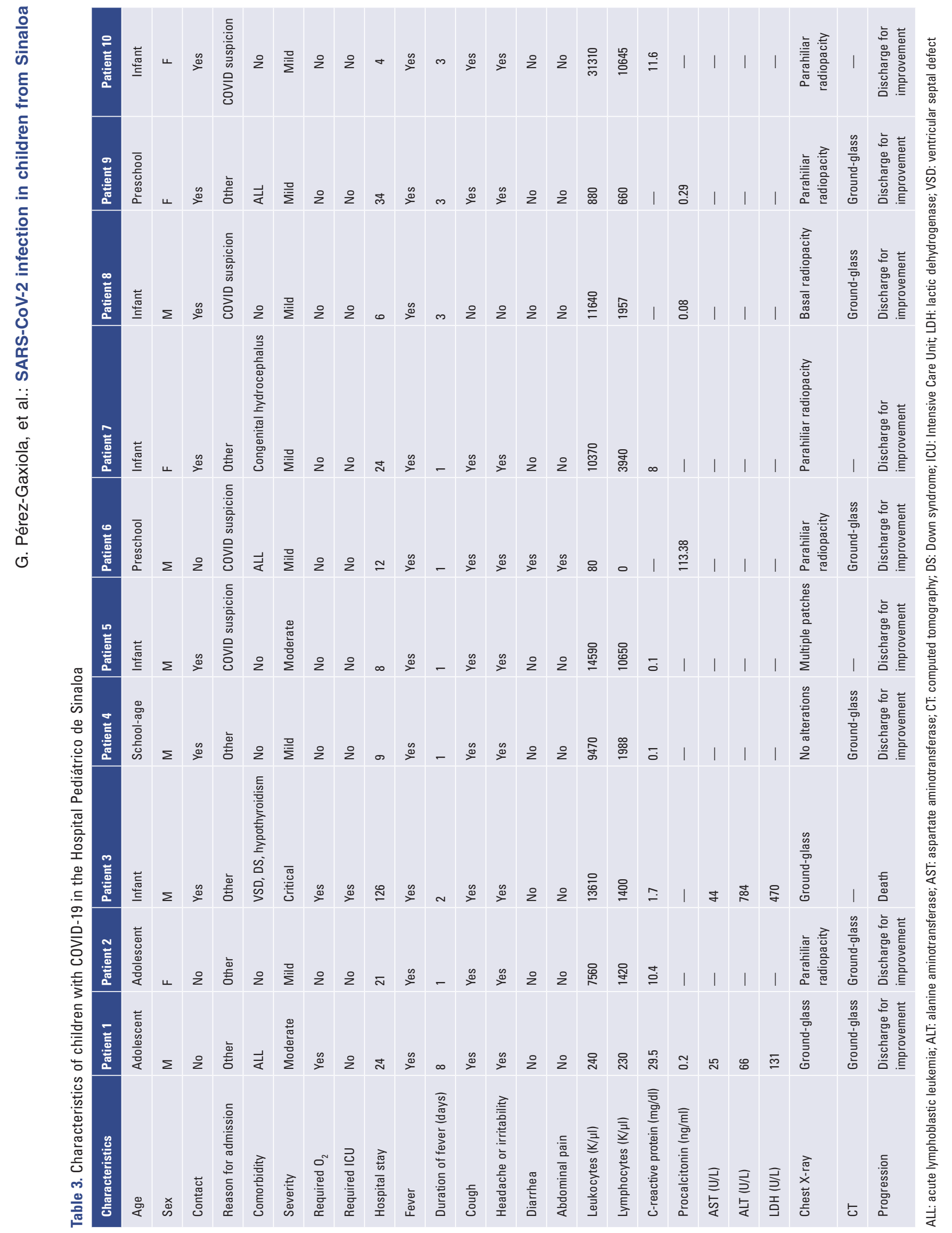


confirmed cases was $1.5 \%$ within the range of previous reports, which varied between $0.8 \%$ and $2.7 \%^{9-11}$. We found more confirmed cases in males and adolescents and school-age children compared with young children; most of the cases were mild or moderate. The most frequent symptoms were fever, cough, and headache (or irritability). These findings are consistent with those published in other case series and systematic reviews $s^{9,10,13-15}$. The presence of ground-glass pattern on lung tomography in children with mild disease or asymptomatic children has also been reported ${ }^{24-26}$. No children that met the full criteria of the multisystem inflammatory syndrome were identified.

Differences in the clinical picture were observed among the children diagnosed at the Hospital Pediátrico de Sinaloa. Only four of the ten children were hospitalized for suspected COVID-19. The other six were admitted for different reasons. However, they later developed a fever and were identified as infected with COVID-19. The RT-PCR (reverse transcriptase-polymerase chain reaction) test should be performed in every patient admitted to the hospital to identify infected individuals. From a practical and economic point of view, testing every patient is not possible. On the one hand, the disease prevalence in children is lower than in adults ${ }^{27,28}$; on the other hand, resources are limited for many tests. Identifying seven asymptomatic children in the state series may also have implications for transmission in the community and should be considered from an epidemiological surveillance point of view.

Although most patients in this series had an asymptomatic, mild, or moderate infection, the possibility of complications is always present in children, especially those with comorbidities ${ }^{11,17,18}$. All three deaths occurred in patients with other pathologies. The proportion of severe or critical children should be small; however, considering the nationwide case increase, this may represent a logistical challenge for pediatric or general hospitals. The two SARS-CoV-2 positive neonates indicate that the possibility of infection exists and should be considered in maternity hospitals, although this group's frequency is also low. Even so, the burden of care should be less than that caused annually by the influenza virus ${ }^{16}$.

This study has limitations. First, only $70 \%$ of the cases could be contacted to corroborate the evolution and define the disease severity. Although we made an effort to include every patient by making two phone calls and sending a message through WhatsApp, we could not contact all. Second, the description of the symptoms from the moment of diagnosis is subjective. Third, laboratory tests and imaging studies results were limited to patients attending the Hospital Pediátrico de Sinaloa, which were ordered based on the attending physician's judgment. Findings may vary for children who were not hospitalized or who were admitted to other institutions.

During the first 3 months of the pandemic, SARS-CoV-2 infection in children was mostly asymptomatic or mild in Sinaloa. The possibility of complications exists, especially in children with comorbidities. As long as outbreaks continue, pediatric cases' epidemiologic surveillance should remain to define transmissibility in children and define public policies for returning to school.

\section{Ethical disclosures}

Protection of human and animal subjects. The authors declare that no experiments were performed on humans or animals for this study.

Confidentiality of data. The authors declare that they have followed the protocols of their work center on patient data publication.

Right to privacy and informed consent. The authors have obtained the written informed consent of the patients or subjects mentioned in the article. The corresponding author has this document.

\section{Conflicts of interest}

The authors declare that they have no conflicts of interest.

\section{Funding}

None.

\section{Acknowledgments}

We want to thank Dr. Rafael Félix Espinoza and Public Health Specialist Silvia Karina Meza Rodríguez, from the Servicios de Salud de Sinaloa (Sinaloa Health Services), for their support in carrying out this study.

\section{References}

1. Li Q, Guan X, Wu P, Wang X, Zhou L, Tong Y, et al. Early transmission dynamics in Wuhan, China, of novel coronavirus-infected pneumonia. N Engl J Med. 2020;382:1199-207.

2. Lu R, Zhao X, Li J, Niu P, Yang B, Wu H, et al. Genomic characterisation and epidemiology of 2019 novel coronavirus: implications for virus origins and receptor binding. Lancet. 2020;395:565-74.

3. Johns Hopkins University and Medicine. Coronavirus Resource Center. COVID-19 Dashboard by the Center for Systems Science and Engineering (CSSE). Baltimore: Johns Hopkins University of Medicine; 2020. Available from: https://www.coronavirus.jhu.edu/map.html. 


\section{G. Pérez-Gaxiola, et al.: SARS-CoV-2 infection in children from Sinaloa}

4. Huang C, Wang Y, Li X, Ren L, Zhao J, Hu Y, et al. Clinical features of patients infected with 2019 novel coronavirus in Wuhan, China. Lancet. 2020;395:497-506.

5. Zeng LK, Tao XW, Yuan WH, Wang J, Liu X, Liu ZS. First case of neonate with COVID-19 in China. Zhonghua $\mathrm{Er} \mathrm{Ke} \mathrm{Za} \mathrm{Zhi.}$ 2020;58:279-80.

6. Mogharab V, Pasha AM, Javdani F, Hatami N. The first case of COVID-19 infection in a 75-day-old infant in Jahrom City, South of Iran. J Formos Med Assoc. 2020;119:995-7

7. Park JY, Han MS, Park KU, Kim JY, Choi EH. First pediatric case of coronavirus disease 2019 in Korea. J Korean Med Sci. 2020;35:1-7.

8. Díaz CA, Maestro ML, Pumarega MT, Antón BF, Alonso CR. First case of neonatal infection due to SARS-CoV-2 in Spain. An Pediatr (Barc) 2020;92:237-8.

9. Dong $\mathrm{Y}, \mathrm{Mo} X, \mathrm{Hu} \mathrm{Y}, \mathrm{Qi} \mathrm{X}$, Jiang $\mathrm{F}$, Jiang Z, et al. Epidemiological characteristics of 2143 pediatric patients with 2019 coronavirus disease in China. Pediatrics. 2020;58:712-3.

10. CDC COVID-19 Response Team. Coronavirus disease 2019 in children-United States, February 12-April 2, 2020. MMWR Morb Mortal Wkly Rep. 2020;69:422-6.

11. Tagarro A, Epalza C, Santos M, Sanz-Santaeufemia FJ, Otheo E, Moraleda C, et al. Screening and severity of coronavirus disease 2019 (COVID-19) in children in Madrid, Spain. JAMA Pediatr. 2020; In press, doi: 10.1001/jamapediatrics.2020.1346

12. Wu Q, Xing Y, Shi L, Li W, Gao Y, Pan S, et al. Coinfection and other clinical characteristics of COVID-19 in children. Pediatrics. 2020;146:1-9.

13. Castagnoli R, Votto M, Licari A, Brambilla I, Bruno R, Perlini S, et al Severe acute respiratory syndrome coronavirus 2 (SARS-CoV-2) infection in children and adolescents: a systematic review. JAMA Pediatr. 2020;174:882-9

14. Xia W, Shao J, Guo Y, Peng X, Li Z, Hu D. Clinical and CT features in pediatric patients with COVID-19 infection: different points from adults. Pediatr Pulmonol. 2020;55:1169-74.

15. Mantovani A, Rinaldi E, Zusi C, Beatrice G, Saccomani MD, Dalbeni A Coronavirus disease 2019 (COVID-19) in children and/or adolescents: a meta-analysis. Pediatr Res. 2020; In press, doi: 10.1038/s41390-020 1015-2.

16. Bhopal S, Bagaria J, Bhopal R. Children's mortality from COVID-19 compared with all-deaths and other relevant causes of death: epidemiological information for decision-making by parents, teachers, clinicians and policymakers. Public Health. 2020;185:19-20.
17. Chao JY, Derespina KR, Herold BC, Goldman DL, Aldrich M, Weingarten $\mathrm{J}$, et al. Clinical characteristics and outcomes of hospitalized and critically III children and adolescents with coronavirus disease 2019 (COVID-19) at a tertiary care Medical Center in New York city. J Pediatr. 2020;223:14-9.

18. Shekerdemian LS, Mahmood NR, Wolfe KK, Riggs BJ, Ross CE, McKiernan CA, et al. Characteristics and outcomes of children with coronavirus disease 2019 (COVID-19) infection admitted to US and Canadian pediatric intensive care units. JAMA Pediatr. 2020;174:868-73.

19. World Health Organization. Multisystem Inflammatory Syndrome in Children and Adolescents Temporally Related to COVID-19. Geneva: World Health Organization; 2020. Available from: https://www.who.int/news$\mathrm{room} / \mathrm{commentaries/detail/multisystem-inflammatory-syndrome-in-chil-}$ dren-and-adolescents-with-covid-19.

20. Toubiana J, Poirault C, Corsia A, Bajolle F, Fourgeaud J, Angoulvant F, et al. Kawasaki-like multisystem inflammatory syndrome in children during the COVID-19 pandemic in Paris, France: a prospective observational study. BMJ. 2020;369:1-7.

21. Verdoni L, Mazza A, Gervasoni A, Martelli L, Ruggeri M, Ciuffreda M, et al. An outbreak of severe Kawasaki-like disease at the Italian epicentre of the SARS-CoV-2 epidemic: an observational cohort study. Lancet. 2020;395:1771-8

22. Licciardi F, Pruccoli G, Denina M, Parodi E, Taglietto M, Rosati S, et al. SARS-CoV-2-induced Kawasaki-like hyperinflammatory syndrome: a novel COVID phenotype in children. Pediatrics. 2020;146:1-5.

23. World Health Organization. Clinical Management of COVID-19. Interim Guidance. Geneva: World Health Organization; 2020. Available from: https://www.who.int/publications/i/item/clinical-management-of-covid-19.

24. Li W, Cui H, Li K, Fang Y, Li S. Chest computed tomography in children with COVID-19 respiratory infection. Pediatr Radiol. 2020;50:796-9.

25. Liu H, Liu F, Li J, Zhang T, Wang D, Lan W. Clinical and CT imaging features of the COVID-19 pneumonia: focus on pregnant women and children. J Infect. 2020;80:e7-13.

26. Lu X, Zhang L, Du H, Zhang J, Li YY, Qu J, et al. SARS-CoV-2 infection in children. N Engl J Med. 2020;382:1663-5.

27. Davies NG, Klepac P, Liu Y, Prem K, Jit M, CMMID COVID-19 Working Group, et al. Age-dependent effects in the transmission and control of COVID-19 epidemics. Nat Med. 2020;26:1205-11.

28. Parri N, Lenge M, Buonsenso D, Coronavirus Infection in Pediatric Emergency Departments (CONFIDENCE) Research Group. Children with COVID-19 in pediatric emergency departments in Italy. N Engl J Med. 2020;383:187-90. 